\title{
Effect of partial replacement of fishmeal with Eichhornia crassipes on growth and survival of Labeo rohita (Hamilton, 1822) juveniles
}

\author{
M. R. Patel ${ }^{1 *}$, K. H. Vadher ${ }^{1}$, R. R. Mer ${ }^{1}$, K. G. Baraiya ${ }^{2}$ and K. V. Tandel ${ }^{1}$ \\ ${ }^{1}$ Department of Aquaculture, College of fisheries, Junagadh Agricultural University, Veraval-362265 (Gujarat), \\ INDIA \\ ${ }^{2}$ Department of Harvest and Post-Harvest Technology, College of Fisheries, Junagadh Agricultural University, \\ Veraval-362 265 (Gujarat), INDIA \\ *Corresponding author. E-mail: mika.pate19@gmail.com
}

Received: December 29, 2015; Revised received: June 28, 2016; Accepted: August 27, 2016

\begin{abstract}
The objective of the study was to find out the effect of partial replacement of fish meal in the diet of $L a b e o$ rohita juveniles. In this experiment, the data pertaining to growth, survival rate, feed conversion ratio, protein efficiency ratio of $L$. rohita at partial replacement of fishmeal with $E$. crassipes were evaluated. For that purpose fry of approximately equal weight $(57.97 \mathrm{mg} \pm 1.25)$ were distributed in groups of 15 to each four aquaria at $0 \%(\mathrm{~T} 1), 10 \%$ (T2), 20\% (T3), 30\% (T4) and 40\% (T5) inclusion levels of aquatic macrophyte, Eichhornia crassipes. Maximum mean weight gain $(235.25 \pm 11.04 \mathrm{mg})$ was observed in T1 and minimum (165.06 $\pm 10.93 \mathrm{mg})$ was observed in T5 at the end of the experiment. Among the treatments tested, the highest survival $(89.99 \% \pm 1.93)$ was recorded in treatment T1 and minimum was found in T4 $(79.99 \% \pm 2.72)$. Lowest FCR was recorded in treatment T3 $(2.02 \pm$ $0.39)$ and highest was found in T5 (3.08 \pm 0.59$)$. Higher SGR was observed in treatment T1 $(297.15 \pm 18.78 \%)$ and minimum was observed in T5 (182.74 $\pm 18.45 \%)$. The study revealed a decrease in the growth performance indices as the percentage of water hyacinth increases. In present study also there was not much difference in growth rate upto $20 \%$ incorporation of $E$. crassipes in the diet. Also, significant difference was observed among treatments with respect to feed utilization $(\mathrm{P}<0.05)$.
\end{abstract}

Keywords: Feed conversion ratio, Fish meal, Growth performance, Labeo rohita, Water hyacinth

\section{INTRODUCTION}

India is the second largest producer of fish in the world contributing to $5.5 \%$ of global fish production. Freshwater aquaculture contributes over $95 \%$ of the total aquaculture production. Carps form the mainstay of aquaculture practice in India contributing over $85 \%$ of the total aquaculture production. The world total production of rohu is 1167315 tonnes in 2010 (FAO, 2012). Rohu, Labeo rohita is one of the most cultured indigenous fish in Indian subcontinent, contributes to about $35 \%$ of the total Indian major carp production. India contributes around 3.6 million tonnes to world freshwater fish production in 2009 (FAO, 2009). In fish culture practices around 50\% of the production cost is due to feed only. The cost of feed depends mainly on the types of protein ingredients included in it. Replacement of fishmeal by cost effective proteins is a priority research in aquaculture throughout the world; because of growing scarcity of quality fishmeal supply and escalation of its cost. Various terrestrial and aquatic macrophytes contain good amount of proteins. (Sheeno and Sahu, 2006; Sulieman and Lado, 2011) have suggested that the use of plant proteins in fish diets will reduce feed cost, which will also assist in reducing the total dependence on fishmeal as the protein source. Eichhornia crassipes, commonly called water hyacinth is a good plant protein source and is easily available in natural water body by Chakrabarti (1998). L. rohita is one of the most cultured indigenous fish in Indian subcontinent. Therefore, the present study was undertaken to find out the effect of partial replacement of fishmeal with aquatic macrophyte on growth and survival of Labeo rohita juveniles.

\section{MATERIALS AND METHODS}

Experimental fish: Labeo rohita was selected for the present experiment. The rationale of its selection was that it has excellent growth rate, easy availability, wide distribution, commercial importance and tastiest fishes among the Indian major carp. Fry of L r rohita were obtained from Government fish farm and acclimatized for 15 days interval in laboratory condition on the feed supplement containing rice bran and Groundnut oil cake (GNOC) in order to habituate them for artificial feeding. Thereafter, during experimental period of 60 days, the fishes were fed with formulated artificial diets @ 5\% body weight/day. The weight of fry were measured after every 15 days and based on the in- 
crease in body weight of fry and their ration was readjusted @ 5\% of their body weight twice daily.

Experimental diets: The present experiment was undertaken to utilize the aquatic weeds and fishmeal to prepare the experimental diet. The ingredients, i.e. rice bran, tapioca starch, animal oil, plant oil were also used. Eichhornia were procured from local area and were dried and grinded to powder form. Five diets were formulated in which fish meal was replaced with Eichhornia meal at $0 \%, 10 \%, 20 \%, 30 \%$ and $40 \%$ levels. The diets were fortified with vitamins and minerals.

Experimental procedure: The experiment was carried out in a completely randomized design (CRD) and consisted of 5 treatments with four replicates for each treatment. L. rohita juveniles $(56.48 \mathrm{mg} \pm 0.94)$ were stocked at 15 nos. /plastic aquarium tank ( 2 x $2 \times 1$ feet) filled with 35 liters of filtered fresh water. Continuous aeration was provided throughout the experimental period in order to maintain dissolved oxygen level in each aquarium. The study was conducted for 60 days. The water quality parameters, temperature, $\mathrm{pH}, \mathrm{DO}$, hardness were analysed through the methods outlined by APHA, 2012).

Statistical analysis: All data presented are expressed as means \pm standard error and was subjected to two way analysis of variance (ANOVA), followed by Duncan's Multiple Range Test with the help of SPSS-16.0 version software (Duncan, 1955).

\section{RESULTS AND DISCUSSION}

In the present study, the chief ingredients of experimental diets at different proportions include Eichhornia, fishmeal, rice bran, tapioca powder, vitamin and minerals, animal oil and plant oil are shown in Table 1. The proximate analysis of Eichhornia based experi- mental diets are recorded in Table 2. The growth performance characteristic of the fry fed Eichhornia is shown in Table 3.

Feeds from plant origin have an excellent amino acid profile and reported to be effective and less expensive ingredients for formulation of artificial fish diets reported by Mohapatra and Patra (2013). For the past several years, one of the main directions in improving fish feeds has been the search for protein source alternatives to fish meal and determining their nutritional suitability in diets. In the past few decades, feeds from plant origin have been accepted for Indian major carps because the growth observed in this fish has been reported to be as good as that obtained with the traditional feed. In tropical developing countries, where algal production rates are high, algae have been receiving increasing attention as an alternate protein possessing relatively high protein content $(50-65 \%)$, which may be included in balanced fish feeds by Suleiman and Lado (2011). The current study demonstrated that the four inclusion level of water hyacinth experimental feed supported the growth for L. rohita fry. Thus, incorporation level up to $40 \%$ Eichhornia meal to replace the fish meal in formulated diet did not exert any adverse effect on growth Performance of L. rohita fry. Growth performance of $L$. rohita fry fed with Eichhornia meal based feed for 60 days shows that there was a decreasing trend with increasing level of Eichhornia feed from $10 \%$ to $40 \%$ replacement. It has also been observed that the growth performance of rohu fry in $20 \%$ replacement was less than the $0 \%$ replacement of Eichhornia feed so far as the protein content in respective replacement was concerned. It proves that, although animal protein is essential for the growth of carp, plant protein has no less importance for the same cause. It is apparent from the results of the present

Table 1. Percentage composition of Eichhornia meal based experimental feed.

\begin{tabular}{lccccc}
\hline \multirow{2}{*}{ Ingredients } & \multicolumn{5}{c}{ Percentage inclusion of Eichhornia } \\
\cline { 2 - 6 } & $\mathbf{0 \%}$ & $\mathbf{1 0 \%}$ & $\mathbf{2 0 \%}$ & $\mathbf{3 0 \%}$ & $\mathbf{4 0 \%}$ \\
\hline Fish meal & 49 & 46 & 43 & 40 & 37 \\
Eichhornia & 00 & 10 & 20 & 30 & 40 \\
Rice bran & 20.5 & 17 & 13.5 & 10 & 6.5 \\
Tapioca powder & 20.5 & 17 & 13.5 & 10 & 6.5 \\
Vitamins \& minerals & 2 & 2 & 2 & 2 & 2 \\
Animal oil & 4 & 4 & 4 & 4 & 4 \\
Plant oil & 4 & 4 & 100 & 100 & 4 \\
Total & 100 & 100 & & 4 & 100 \\
\hline
\end{tabular}

Table 2. Proximate composition of experimental feeds.

\begin{tabular}{llllll}
\hline Eichhornia feed & Crude protein (\%) & Crude lipid (\%) & Ash (\%) & Moisture (\%) & Crude fibre (\%) \\
\hline $0 \%$ & 33.32 & 8.8 & 13.2 & 2.5 & 5.1 \\
$10 \%$ & 33.43 & 8.1 & 12.0 & 3.1 & 6.9 \\
$20 \%$ & 33.54 & 7.9 & 12.2 & 3.8 & 7.4 \\
$30 \%$ & 33.66 & 7.6 & 12.5 & 3.3 & 7.9 \\
$40 \%$ & 33.72 & 7.1 & 12.1 & 3.7 & 8.2 \\
\hline
\end{tabular}


M.R. Patel et al. / J. Appl. \& Nat. Sci. 8 (3): 1659 - 1662 (2016)

Table 3. Growth performance (mg) of $L$. rohita fry fed E. crassipes based feed for 60 days $( \pm \mathrm{SE})$.

\begin{tabular}{llllllll}
\hline $\begin{array}{l}\text { Treat- } \\
\text { ment }\end{array}$ & Replicate & $\begin{array}{l}\text { Initial } \\
\text { weight }\end{array}$ & Final weight & SGR & Survival & FCR & PER \\
\hline T1 & R1 & 59.40 & 219.46 & 266.77 & 93.33 & 2.12 & 1.13 \\
& R2 & 56.13 & 267.00 & 351.45 & 93.33 & 1.95 & 1.52 \\
& R3 & 58.67 & 233.50 & 291.38 & 86.66 & 1.97 & 1.16 \\
& R4 & 53.67 & 221.07 & 279.00 & 86.66 & 2.05 & 1.45 \\
& Mean & $56.96 \pm 1.30$ & $235.25 \pm 11.04^{\mathrm{a}}$ & $297.15 \pm 18.78^{\mathrm{a}}$ & $89.99 \pm 1.93^{\mathrm{a}}$ & $2.02 \pm 0.39^{\mathrm{a}}$ & $1.32 \pm 0.99^{\mathrm{a}}$ \\
T2 & R1 & 54.00 & 233.00 & 298.33 & 80.00 & 2.29 & 0.23 \\
& R2 & 58.67 & 258.40 & 332.88 & 86.66 & 2.34 & 1.36 \\
& R3 & 58.13 & 181.23 & 205.17 & 86.66 & 2.35 & 0.76 \\
& R4 & 55.53 & 191.00 & 225.78 & 86.66 & 2.41 & 1.02 \\
& Mean & $56.58 \pm 1.10$ & $215.90 \pm 18.07^{\mathrm{ab}}$ & $265.54 \pm 30.05^{\mathrm{ab}}$ & $84.99 \pm 1.67^{\mathrm{a}}$ & $2.34 \pm 0.25^{\mathrm{b}}$ & $0.84 \pm 0.24^{\mathrm{a}}$ \\
T3 & R1 & 59.22 & 186.83 & 212.68 & 80.00 & 2.45 & 0.95 \\
& R2 & 58.23 & 177.42 & 198.65 & 80.00 & 2.69 & 0.19 \\
& R3 & 56.22 & 234.58 & 297.27 & 86.66 & 2.43 & 1.29 \\
& R4 & 58.23 & 262.66 & 340.72 & 80.00 & 2.04 & 1.27 \\
& Mean & $57.97 \pm 0.63$ & $215.37 \pm 20.12^{\mathrm{ab}}$ & $262.33 \pm 34.02^{\mathrm{ab}}$ & $81.66 \pm 1.67^{\mathrm{a}}$ & $2.40 \pm 0.13^{\mathrm{b}}$ & $0.93 \pm 0.26^{\mathrm{a}}$ \\
& R1 & 56.47 & 215.53 & 265.10 & 86.66 & 2.42 & 1.28 \\
& R2 & 55.27 & 141.16 & 143.15 & 80.00 & 2.62 & 0.69 \\
& R3 & 55.73 & 175.08 & 198.92 & 73.33 & 2.62 & 0.66 \\
& R4 & 54.33 & 176.28 & 203.25 & 80.00 & 2.42 & 0.17 \\
& Mean & $55.45 \pm 0.45$ & $177.01 \pm 15.20^{\mathrm{bc}}$ & $202.60 \pm 24.92^{\mathrm{b}}$ & $79.99 \pm 2.72^{\mathrm{a}}$ & $2.52 \pm 0.58^{\mathrm{b}}$ & $0.70 \pm 0.23^{\mathrm{a}}$ \\
& R1 & 55.20 & 176.16 & 201.60 & 80.00 & 3.22 & 0.98 \\
& R2 & 55.47 & 169.50 & 190.05 & 73.33 & 3.10 & 0.41 \\
& R3 & 55.20 & 181.50 & 210.50 & 86.66 & 3.10 & 0.96 \\
& R4 & 55.80 & 133.10 & 128.83 & 100 & 2.93 & 0.71 \\
& Mean & $55.41 \pm 0.14$ & $165.06 \pm 10.93^{\mathrm{c}}$ & $182.74 \pm 18.45^{\mathrm{b}}$ & $84.99 \pm 5.69^{\mathrm{a}}$ & $3.08 \pm 0.59^{\mathrm{c}}$ & $0.76 \pm 0.27^{\mathrm{a}}$ \\
\hline
\end{tabular}

study that fry fed with $0 \%$ inclusion of Eichhornia meal showed better growth performance which was significantly different $(\mathrm{P}<0.05)$ from the $20 \%$ inclusion of the Eichhornia diet. The Eichhornia feed at $40 \%$ replacement exhibited significant impact on the growth performance of the rohu fry.

Mohapatra and Patra (2013) revealed that water hyacinth probably affects the feed conversion ratio and the feed utilization by the Cyprinus carpio fry. Fagbenro and Arowosegbe (1991) reported that inclusion of water hyacinth significantly increase the crude fiber content of feed. Higher fiber in feed plays a significant role in digestion of feed. Another study has observed that lipid component reduces as the water hyacinth inclusion levels increases followed by optimum growth in fish (Rumsey, 1993).

Replacement of water hyacinth meal for $20 \%$ fish meal promotes higher $(\mathrm{p}<0.05)$ final weight than feeding fish meal up to $40 \%$ replacement.

Survival was generally high in all the fry fed with the water hyacinth supplemented diets. The cost of production and the benefits positively favoured all treatments since the values computed are > 1.0 which shows an increase in the fish value above the amount invested. This notwithstanding, more monetary profit awaits a farmer when $20 \%$ of water hyacinth meal is used to replacement fish meal in the diets of rohu fry.

In recent years increasing attention has been given on formulation of cost effective protein riches artificial feed for intensive fish culture (Luo et al., 2004). Increase in dietary protein has often been associated with higher growth rate in many fish species as fish require high protein content diet for better growth reported by Deng et al. (2006). The results of various experiments indicate that the most important significant factor that influences growth, survival and yield of fish are the quantity and quality of dietary protein of fish feed ( $\mathrm{Sa}$ et al., 2006). Therefore, considerable research effort is needed to determine the quantity and quality of dietary protein necessary to achieve optimum growth performance of fish. To formulate low cost feed, ingredients from plant and animal sources are used to fulfill the protein requirement of the fish meal, fully or partially. The inter-relationship between the dietary energy requirement and the growth of fish and the importance of proper protein nutrition has been well established. So, fish nutritionists pay greater attention to reduce the cost of artificial diets by introducing alternative protein sources from plant and animal (Das et al., 1991). This result is similar to the report of (Lim and Doming, 1989; Hasan et al, 1990, 1994; Klinavee et al, 1990; Fagbenro and Arowosegbe, 1991; Sheeno and Sahu, 2006; Sulieman and Lado, 2011) who have demonstrated the use of several species of Eichhornia as partial replacement for fishmeal in the diet of fish and other animals. The study clearly showed that fish fed 
diet with $20 \%$ inclusion of Eichhornia perform excellently well compared to other treatment.

Recently wide varieties of non conventional protein of both plant and animal origin have been evaluated and used to formulate fish diet. Therefore, efforts are now being directed in different part of the globe to find alternate protein sources of good quality without affecting adverse effect on growth performance of fish. Studies have been carried out on the development of new feed formulation for carps in fresh water aquaculture system. The experiment concludes that fish meal could not be replaced totally with plant; however, partial replacement can be done by using Eichhornia meal to reduce the cost without affecting growth rate. The present study revealed that $20 \%$ Eichhornia feed would be optimum for the maximum growth of L. rohita fry. Further, such aquatic weed based feeds are cheaper as compared to the conventional feeds, replacement of aquatic weeds in carp diets would also prove economically viable.

\section{Conclusion}

Based on the results obtained from the present study conducted, it was observed that weight gain and SGR were significantly higher in control diet (Treatment 1) in L. rohita. Lowest FCR was recorded in Treatment 1 but there was no significant difference among treatments. PER and survival rate were also recorded higher in treatment 1 but there was no significant difference. Therefore on the basis of these results it was revealed that the Treatment 1 (i.e. diet prepared without $E$. crassipes) was better for highest weight gain, SGR, PER, survival and lowest FCR whereas treatment 3 diet prepared with $20 \%$ E. crassipes incorporation.

\section{REFERENCES}

APHA (2012). Standard Methods for the Examination of Water and Wastewater, 20th ed. American Public Health Association, the American Water Works Association and the Water Environment Federation,1220.

Chakrabarti, N.M. 1998. Biology, culture \& production of Indian major carps. Delhi (India), Narendra publishing house. p. 47.

Das K.M., Mohanty S.N. and Sarkar S. (1991). Optimum dietary protein to energy ratio for Labeo rohita fingerlings. In Proceedings of the Fourth Asian Fisheries Society, Spec. Publ., 5: 205.

Deng J., Mai K., Ai Q., Zhang W., Wang X., Xu W., et al. (2006). Effects of replacing fish meal with soy protein concentrate on feed intake and growth of juvenile Japanese flounder, Paralichthys olivaceus. Aquaculture, 258: 503-513.
Duncan D.B. (1955). Multiple range and multiple F-tests. Biometrics, 11: 1-42.

Fagbenro O.A. and Arowosegbe I.A. (1991). Utilization of agricultural wastes and by-products in fish feeds production in Nigeria. Proceedings of the VI Annual Conference of Fisheries Society of Nigeria, Lagos, pp. 121-130.

FAO (2009). Fisheries Statistics. Food and Agricultural Organization, Rome, Italy. Available at http:// www.fao.org.

FAO (2012). Fisheries Statistics. Food and Agricultural Organization, Rome, Italy. Available at http:// www.fao.org.

Hasan, M. R. and Roy, P. K. (1994). Evaluation of water hyacinth leaf meal as dietary protein source for Indian major carp, Labeo rohita fingerlings. In : L. M. Chou, A. D.; Munro, T. J.; Lam, T. W.; Chen, L. K. K.; Cheong, J. K.; Ding, K. K.; Hooi, H. W.; Khoo, V. P. E.; Phang, K. F. and Tan, C. H. eds. The Third Asian Fisheries Forum. Manila, Asian Fisheries Society. pp. 671-674.

Hasan, M. R.; Moniruzzaman, M. and Omar Farooque, A. M. (1990). Evaluation of Leucaena and water hyacinth leaf meal as dietary protein sources for the fry of Indian major carp, Labeo rohita (Hamilton). pp. 275-278. In R. Hirano \& I. Hanyu, eds. The Second Asian Fisheries Forum. Manila, Asian Fisheries Society.

Klinavee, S.; Tansakul, R. and Promkuntong, W. (1990). Growth of Nile tilapia (Oreochromis niloticus) fed with aquatic plant mixtures. In R. Hirano \& I. Hanyu, eds. The Second Asian Fisheries Forum. Manila, Asian Fisheries Society. pp. 283-286.

Lim, C. and Doming. (1989). American soybean association utilization of plant protein by warm water fish. USDA ARS. Tropical Aquaculture Research unit. The Oceanic Institute, Hawaii.

Luo Z., Liu Y.J., Mai K., Tian L.X., Liu D.H. and Tan XY. (2004). Optimal dietary protein requirement of grouper Epinephelus coioides juveniles fed isoenergetic diets in floating net cages. Aquaculture Nutrition, 10: 247-252.

Mohapatra, S. B. and Patra, A. K. (2013). Utilization of water hyacinth (Eichhornia crassipes) meal as partial replacement for fish meal on the growth performance of Cyprinus carpio fry. International Research Journal of Biological Sciences. 2 (12): 85-89.

Rumsey G.L. (1993). Fish meal and alternative sources of Protein. Fisheries, 18: 14-19.

Sa R., Pousao-Ferreira P., Oliva-Teles A. (2006). Effect of dietary protein and lipid levels on growth and feed utilization of White Sea bream Diplodus sarus juveniles. Aquaculture Nutrition, 12: 310-321.

Sheeno, T. P. and Sahu N. P. (2006). Use of freshwater aquatic plants as a substitute of fishmeal in the diet of Labeo rohita fry. Journal of Fisheries and Aquatic Science. 1 (2): 126-135.

Sulieman Adam, H. M. and Lado, Ferensio. E. (2011). Nutritional effectiveness of water hyacinth leaves combined with wheat bran and cotton seed cake on the performance of Nile tilapia (Oreochromis niloticus). Online Journal of Animal and Feed Research. 1 (6): 306-309. 